\title{
PERCEIVED EFFECTS OF CORONA-PHOBIA AND MOVEMENT CONTROL ORDER ON NigERIAN POSTGRADUATE STUDENTS IN UNIVERSITI TEKNOLOGI MALAYSIA
}

\section{Sa'adu Isa BASHAR*}

Department of Educational Foundations,

Faculty of Education, Sokoto State University,

PMB 2134, Sokoto, Nigeria.

mmbashar1984@gmail.com

\section{Abdulmumini INDA}

Department of Arts Education,

Faculty of Education, Taraba State University,

PMB 1167, Jalingo, Nigeria.

abuiitizaz@gmail.com

\section{Ramatu Muhammad MAIWADA}

Department of Educational Foundations,

Faculty of Education, Sokoto State University,

PMB 2134, Sokoto, Nigeria.

ramatumaiwada@gmail.com

*Corrosponding author's Email: mmbashar1984@gmai.com

*Corresponding author email: 


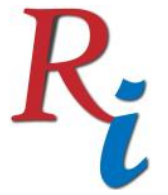

\section{Asia Proceedings of Social Sciences \\ (APSS) \\ www.readersinsight.net/APSS}

\section{A b s t r a c t}

The purpose of this study was to investigate the effects of Corona-phobia and MCO on the Nigerian graduate students in the Universiti Teknologi Malaysia. The study was quantitative and descriptive survey in design. The population of the study was 380 graduate students in the UTM. A total of 191 participants were selected randomly as the sample for the study. The study used an online questionnaire for data collection. Its validity and reliability were 0.7 and 0.8 respectively. Data was analyzed using descriptive statistics (mean and standard deviation). After the analysis, the findings revealed that both corona-phobia and MCO have effects on the students because they resulted in hopelessness, fear and stigma coupled with affecting the educational undertakings of the students. It is thus recommended that the authorities of the institution should introduce online services, academic activities and programmes to enable continuity of the educational activities during the pandemic period and reduce redundancy, anxiety and depression among the students.

\section{Rese a r ch High I ight s}

Highlight 1: the fear of affliction with the Covid19 has engulfed the global community (Goyal et al., 2020) and thus deteriorates every facet of human endeavour including the education (AbuKarim, 2020; Bedford et al., 2020).

Highlight 2: the study examined the possible effects of corona-phobia as well as the movement control order imposed by the Malaysian government in the country on the emotional and academic undertakings of the Nigerian graduate students in the Universiti Teknologi Malaysia.

Highlight 3: the study discovered that corona-phobia and the MCO affect the Nigerian graduate students in many negative ways. Based on this, measures to avoid the effects were recommended.

\section{Research Objectives}

The study sought to find out the effects of corona-phobia and effects of the MCO on the Nigerian postgraduate students in the UTM. It also intended to identify measures for avoiding the likely negative effects on the students for continuous conduct of their educational undertakings in the institution.

\section{Methodology}

The study employed a descriptive survey design in order to seek the responses of the participants based on the subject of investigation (Creswell and Creswell, 2018). The study uses the entire Nigerian postgraduate students (280) in the Universiti Teknologi Malaysia as its population. The study also used Krejcie and Morgan (1970) table for sample size determination and selected 191 participants. Simple random sampling technique was used to 


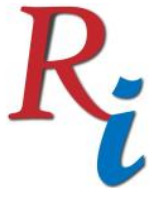

\section{Asia Proceedings of Social Sciences \\ (APSS) \\ www.readersinsight.net/APSS}

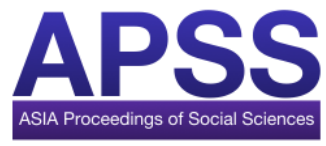

distribute the online-google-form questionnaire for data collection in order to give every member of the population a chance of being selected (Creswell, 2013). Data analysis was made using descriptive method and thus the result was presented in tables of means and standard deviation.

\section{Results}

The result shows that corona phobia develops fear and hopelessness among students ( $\mathrm{M}=4.4475)$, makes students loose self-control $(\mathrm{M}=3.8729)$, develops social stigma among students $(\mathrm{M}=4.5580)$, develops psychological trauma among students $(\mathrm{M}=4.6243)$, discourages students from study and learning $(\mathrm{M}=4.3094)$, discourages academic trust among students $(M=4.1878)$, and denies students group discussion $(M=4.6188)$. The Movement control order restricted the students access to physical library services $(M=4.2431)$, access to physical laboratory services $(M=4.3591)$, access to study room $(M=3.6961)$, face-to-face interaction with the supervisors $(\mathrm{M}=4.6575)$, access to excursion functions and field works $(M=4.5249)$, attending workshops $(M=4.4807)$, attending academic conferences $(M=4.6354)$.

\section{Findings}

Findings of the study that corona-phobia has some psychological effects on Nigerian postgraduate students in UTM as it has developed some fear, hopelessness, loss of self-control, social stigma, emotional trauma, discouraged learning and academic trust as well as group discussion among the students. Similarly, findings indicated that the MCO denied students access to physical library and laboratory facilities, face-to-face interaction with supervisors, access to excursion functions and field works, attending workshops and academic conferences, making academic consultations, and making new academic connections

\section{Acknowledgement}

Efforts of all those that contributed to the success of this research are hereby acknowledged and appreciated.

\section{References}

AbuKarim, M., 2020. Handling Students' Mental Health during MCO. New Straits Times 12.

Bedford, J., Enria, D., Giesecke, J., Heymann, D.L., Ihekweazu, C., Kobinger, G., Lane, H.C., Memish, Z., Oh, M. don, Sall, A.A., Schuchat, A., Ungchusak, K., Wieler, L.H., 2020. COVID-19: towards controlling of a pandemic. Lancet 395, 10151018. https://doi.org/10.1016/S0140-6736(20)30673-5

Creswell, J.W., 2013. Research design: Qualitative, quantitative, and mixed methods 


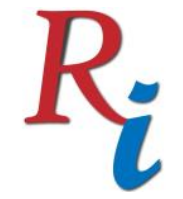

\section{Asia Proceedings of Social Sciences (APSS) \\ www.readersinsight.net/APSS}

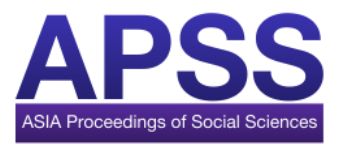

approaches. Sage publications.

Creswell, J.W., Creswell, J.D., 2018. Research Design: Qualitative, Quantitative and Mixed Methods Approaches, 5th ed. Los Angeles: SAGE, USA.

Goyal, K., Chauhan, P., Chhikara, K., Gupta, P., Singh, M.P., 2020. Fear of COVID 2019:

First suicidal case in India! Asian J. Psychiatr. 49, 101989.

https://doi.org/10.1016/j.ajp.2020.101989

Krejcie, R.V., Morgan, D.W., 1970. Determining Sample Size for Research Activities. Educ. Psychol. Meas. 30, 607-610.

Author's Biography

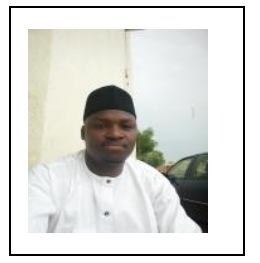

Sa'adu Isa BASHAR is a lecturer in the unit of Educational Management, Department of Educational Foundations, Faculty of Education, Sokoto State University, Sokoto, Nigeria. Currently, he pursues his Doctor of Philosophy (PhD) degree in Education (Educational Management and Administration) at the Universiti Teknologi Malaysia. He attended and presented papers at different national and international conferences. He published many research articles and chapters in many national and international referred journals, Scopus-index journals, book chapters and conference proceedings. He is a member of the Nigerian Association of Educational Administration and Planning (NAEAP). He is also a member of the Primary and Tertiary Teachers' Association of Nigeria (PATTEAN).

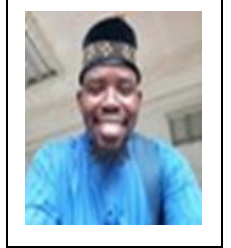

AbdulMumini INDA is a Lecturer of Islamic Education in the Department of Arts Education, Faculty of Education Taraba State University, Jalingo. He attended Central Primary School Karim, Arabic Teachers' College Song, Federal College of Education Yola and Ahmadu Bello University, Zaria Nigeria. Currently he is a Ph.D candidate in the field of Curriculum and Instructions, University Teknologi Malaysia. He published many scholarly arcticles in respectable local and international Journals. And he is an active member of Nigeria Association of Teachers of Arabic and Islamic Studies (NATAIS) and he registered with Teachers' Registeration Council. He is a team member with a renown international conference organisers (Connectingasia) He is the CEO International Centre for Islamic Education, Ardo kola, Taraba State. The author love teaching and research.

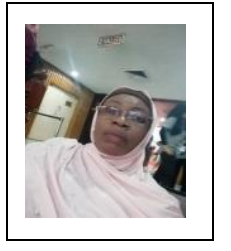

Ramatu Muhammad MAIWADA is a lecturer with the Department of Educational Foundations, Faculty of Education, Sokoto State University, Sokoto, Nigeria. She is presently a PhD student in Guidance and Counselling, Universiti Teknologi Malaysia. 